\title{
In-Group Concept of the Apology Dialogue Statement in Business Comics Pragmatics Perspective
}

\author{
Parastuti \\ Universitas Negeri Surabaya \\ Surabaya, Indonesia \\ parastuti@unesa.ac.id
}

\author{
Ina Ika Pratita \\ Universitas Negeri Surabaya \\ Surabaya, Indonesia \\ inapratita@unesa.ac.id
}

\author{
Roni \\ Universitas Negeri Surabaya \\ Surabaya, Indonesia \\ roni@unesa.ac.id
}

\begin{abstract}
Language as an introduction to the communication of a society, is a means of socialization and inheritance of a country's cultural values. And the service sector is good and orderly, it does not escape the emphasis of the use of several expressions. For example, how to express apology statements stated by people involved in business conversations. The variety of formal and informal languages in a dialogue that says sorry in the business comic "Inshokuten Kanzen Bible Manga de Manabu no Housoku 26 ka you". And also the relationship between a variety of formal and informal languages with Japanese people's social interaction patterns. The research data is a business comic book that has a restaurant business conversation setting. The book is titled "Inshokuten Kanzen Bible Manga de Manabu no Housoku 26 Ka you". And the source of the data are dialogues containing the apology statement. The results of this study are expected to uncover the way Japanese people interact. And of course it will be very useful both for Japanese language learners or workers who are always in relation with Japanese people. Also the people who are the observers of Japanese culture.
\end{abstract} comic

Keywords-in-group concept, apology statement, business

\section{INTRODUCTION}

Language as an introduction to the communication of a society, is a means of socialization and inheritance of a country's cultural values. Every country displays a culture of language and style that can be reflected in the variety of languages it has. Thus, language is said to be a communication tool in a society that has certain functions. One of them is the function of language as a communication tool in the fields of business and services.

Japan is very famous for its good and organized services. And the service sector is good and orderly, it does not escape the emphasis of the use of several expressions. For example, how to express apology statements stated by people involved in business conversation. The phrase 'sorry' for the literal meaning, is not just limited to a speaker who feel guilty. But it has a broader meaning. For example, in the form of rebukes, greetings, or just asking for attention.
To understand the use of the Apology expression with a variety of functions can be known from the various languages used in a particular conversation setting. For example, in a comic that specifically tells the story of a business that focuses on restaurant services. What is meant in the business world above, is the field of services around the things that happen in a restaurant. The dialogue between the characters, in stating this 'expression of apology' can be seen clearly. Because, there is a dialogue that can reflect the variety of languages that exist in the situation.

To be able to understand it better, the apology statement requires that the situation actually occurs. In the comic that is the source of this research data, it is drawn from the dialogues that have developed from the communication between the restaurant owner, the restaurant worker staff and also the dialogue that takes place between the customers of the restaurant. The patterns that occur in Japanese social interaction that is formed from the variety of languages will be seen from how Japanese people think. In other words, certain expressions spoken in a variety of languages can also be a sign of a pattern of social interaction in certain societies as well.

In this research, what kinds of languages can reflect the 'apologies'. Also how the relationship between the characters involved in the dialogue between the speaker and the listener will be detected. For example, the relationship between superiors and subordinates between the owner and his staff, or the relationship between the restaurant and its customers. The data in the form of dialogues stating the expression of apology in the comic "Inshokuten Kanzen Bible Manga de Manabu no Housoku 26 ka you" can reveal that. This comic is a book written by Akira Harada, Morihiko Ishikawa [13].

Data in the form of dialogue with a variety of Formal or Informal languages are linked to the Japanese Social Interaction pattern strategy. The goal above is to be able to describe the relationship between formal and informal language variations with the Japanese people's social interaction pattern strategy. The results of this dialogue analysis discussion are expected to reveal the way they interact. And of course it will be very useful both for Japanese language 
learners or workers who are always in contact with Japanese people. Also people who are observers of Japanese culture.

\section{A. Variety of Languages}

From matters relating to the diversity of the social sources of language speakers and the diversity of language functions, there is such a view. Namely the variation or variety of languages to fulfill its function as a means of interaction in a diverse society.

There are 4 types of variations in language, namely 1) variations in terms of speakers, (2) variations in terms of usage, (3) variations in terms of formality and (4) variations in terms of facilities [5].

Variation in terms of formality, as explained by Martin Joss (1967) in his book The Five Clock [5], divides language variations into 5 types. Namely (a) a variety of standard languages, (b) an official variety, (c) a variety of business or consultative variations, (d) casual variations, and (e) familiar variations.

Official Variety or Formal Variety, namely variations in the language used in state speeches, official meetings, correspondence and so on. Whereas Relaxing or Informal Variety, variations of the language used in informal situations to chat with family or close friends during breaks, exercise, recreation and so on.

Language Variety in the scope of its understanding, is the variation of language according to usage that varies by topic, according to the relationship of the speaker, the interlocutor, the person being talked about, and according to the theme of the conversation. In other words, the variety of languages is the variation of different languages caused by various factors found in society. These factors, for instance, age, education, religion, fields of activity and profession, including the cultural background of the people involved in the interaction

\section{B. Expression of Apology Statement}

To understand the Japanese Apology Statement, so many versions according to some experts depend on which angle the focus of the discussion is. One of them is contained in scientific papers written by Sato [3], stated as follows. The most basic form of apology is as follows, (1)ごめんなさい, (2)すみません, and (3)もうしわけありません。Furthermore, from the three other variations emerged according to the situation and position of the speaker (see Table 1). For example, the following corresponds to a variety of language uses ranging from informal to formal variations.

In addition to what is written in the table, there are several expressions of apology that include informal languages. Namely, before (1), there are わるい、許 してくれ and others
Table 1: Expressions of apology statements

\begin{tabular}{|c|l|}
\hline $\begin{array}{c}\text { Expression of Apology } \\
\text { Statement }\end{array}$ & $\begin{array}{l}\text { Another Variations According } \\
\text { to the Level of Error and } \\
\text { Position of the Other Person }\end{array}$ \\
\hline (1) ごめんなさい & ごめん \\
\hline (2) すみません & すみませんでした \\
\hline (3) もうしわけありません & $\begin{array}{l}\text { 申し訳ございませんでした, } \\
\text { 申し訳ありませんでした, } \\
\text { 申し訳ない }\end{array}$ \\
\hline
\end{tabular}

Then based on the function of its use, Sato [3] takes an example すみません to explain some of the functions and examples of sites using the apology statement in an interaction or dialog. Apology statement すみません considered by Sato to be able to enter into formal and informal forms. Therefore, to explain the function of this apology statement, use the Apology Statementすみません.

Apology statement すみません, in some functions, besides to apologize for making the opponent bother is the guilty feeling of the speaker, because he feels it has been morally or materially harmful. Here are some other functions.

1. Its function is as a thank you, when receiving something

a「こんな忙しい時期、相談にのっていただいて、

みません」

b （お水を出してもらって）

「あ、すみません」

2. Its function is as an opening to ask something

a（人に話しながら）

「すみません、上能駅にはどう行ったらいいのでし

ようか?」

3. Its function is as a substitute for greetings

a（退出する）

「では、今日はこれで、すみません」

4. Its function is as an opening of command sentence or the speaker expects that the interaction partner will do what he wants

a「すみませんが、事務に資料を取ってもらえますか ?」

5. Its function is to plead people who are higher in position and the speaker positions himself lower than the opponent's interactions 


\section{a「すみませんが、Y社長にはお会いいただけません \rfloor}

6. It functions as a refusal or an offer of the opponent' interaction

a A:「僕たちつき合わない?」

\section{B:「すみません」 *「ごめんなさい」の方が自然}

Those are the function descriptions of using an apology statement, which is represented by an apology statement 「すみません」。

3. The Concept of "UchiSoto”（「ウチ・ソト」の概念）/ In-Group Concept

The concept of systematic structure of Japanese society's social concepts, reviewed by two experts of Japanese social structure. First, Social Expert Nakane Chie [11] put more emphasis on ou 関係 Jouge Kankei, namely the relationship between Subordinate Superiors in the social structure of Japanese society. The concept of systematic structure of Japanese society's social concepts, in theory from the point of view of a social expert Nakane Chie [11] who emphasizes more on Jouge Kankei, namely the vertical line relationships in the social structure of Japanese society.

Within the data in the form of dialogs between the restaurant owner and restaurant staff, and restaurant owners and expert consultants on restaurants, etc., can illustrate the pattern of Interaction in Japanese Social Society.

Second, Konsep Uchi- Soto " (「ウチ ・ ソトの 概念） in the perspective of Japanese culture that proposed by Takeo Doi [6] in Anatomy of Dependency 甘 え 構造 (1992). Also the concept of "Uchi-Soto") 「ウ チ ・ ソ」の 概念) in the perspective of Japanese culture put forward by Takeo Doi [6]. Amae's Behavior in Dependent Anatomy 甘 $え$ 構造, research from a Japanese social expert Takeo Doi [6], shows how these Japanese individuals interact horizontally between one another.

In this study, what is meant by（「ウチ」の 概 念） is, when the speaker positions himself in the same area as the opponent's interaction. Whereas the （「ソト」の 概念） is if the speaker positions himself in the same area as the opponent's interaction.

Both of these will be seen in the data in the form of dialogs between the restaurant owner or restaurant staff and various guest customer characters, complete with various conflicts that accompany can illustrate this.

\section{RESUltS AND DISCUSSION}

The following are the examples related to some of the dialogues that exist in Japanese business comics, specifically the restaurant business and Japanese language business. The dialogues stated that the apology expression in the comic "Inshokuten Kanzen Bible Manga de Manabu no Housoku 26 ka you" can reveal that. This comic is a book written by Akira Harada, Morihiko Ishikawa [13].

The following dialogues will all included in the Indonesian translation translated by Nikkei Bussines Publications. The goal is that the apology statement can be better understood even by Indonesian shokyuu level students. Then for easier understanding, consider table 2.

Table 2: Illustrations and pictures with their meaning

\begin{tabular}{|l|l|}
\hline Picture / illustration & \multicolumn{1}{|c|}{ Meaning } \\
\hline & $\begin{array}{l}\text { Position of the speaker towards the } \\
\text { opponent's interaction }\end{array}$ \\
\hline & $\begin{array}{l}\text { The speaker positions himself in the } \\
\text { same area as the opponent's interactions } \\
\text { The speaker positions himself NOT the } \\
\text { same as the area of the opponent's } \\
\text { interaction. }\end{array}$ \\
\hline
\end{tabular}

第1条 Story $\quad$ 1： 離れた常連客を取り戻せ $\quad$ (p.13) and (p.17)

Returning Older Subscription Guests who hasn't visited in a long time

Masa (M) and Yukari (Y) were friends since childhood. A few years, they did not meet. Before meeting, Yukari wrote a letter, asking for a consultation regarding her father's restaurant.

人物 人物 situations and people involved in the conversationY : Yukari ゆかり

M : Mr. Masa マサ（ゆかりの馴染みな友人）

AY: Yukari's father / (PR) Restaurant Owner: ゆかりのおさん・レスの のののオ -

IY: Ms. Yukari ゆかりのお母さん

$\mathrm{T}$ : Visitor 2 竹田（よく来るお客さん）

Conversation situation:

Ms. Yukari (D) forced Yukari's father (C) to consult with Mr. Masa. But getting an angry response by Yukari's father

IY:

「アナタせっかくの機会ですからお話

を伺ったら?

$\mathrm{AY}:\lceil お$ 前は黙てろ!」

「料理がおいしければお客さんは必

ず帰ってくる」

AY:「マサさん、悪いけど帰ってくれ

!。」

Y:「お父さん！」
IY: "Sir, this is a good opportunity, why not just talk!"

AY: "You stay still"

"As long as the cuisine is delicious, guests will return"

AY: "Sir, sorry, but go home!" Y: "DAD!" 


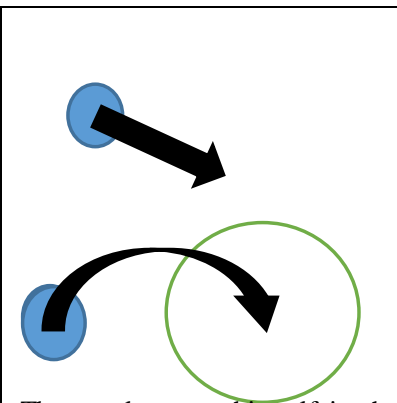

The speaker puts himself in the same area as the opponent's interactions
The speaker is getting position as the speaker (Yukari's father). Compared to opposing interactions, the speaker is older, and socially related, is higher. His interaction opponent (Pak Masa) is his son's friend (Yukari).

Speakers of their interaction partners use a variety of informal languages. Based on the choice of using the expression apology 「悪い けど」 serves as a rejection

The vocabulary choice is reinforced by command words that can be used in intimate or familiar situations, that is, 「帰 つてくれ」 and there are exclamation marks, as expressions of anger.

From the point of view of Interaction Patterns in Japanese Social Society, the speaker positions himself as the 'person in the group'

(「チ」の 概念) towards his opponent.

\section{Conversation situation:}

数 日後 A few days later, a subscribed visitor, Pak Takeda (T) came, and said sorry, for a long time not stopping by the restaurant
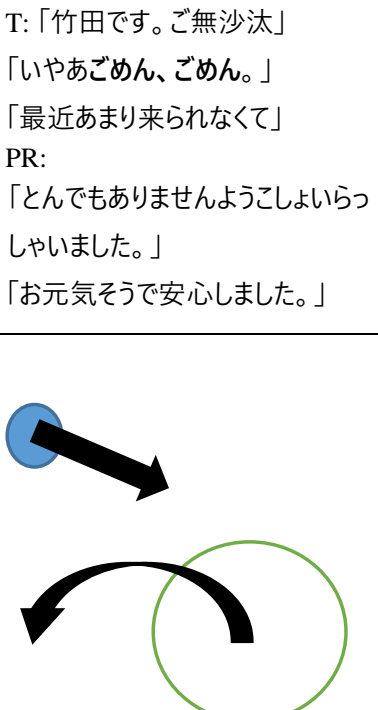

The speaker puts himself NOT the same as the area of the opponent's interactions
"T "I am Takeda, long time no see" "Ah sorry, I am sorry" "I can't come lately" PR: "It's alright, welcome" "I'm relieved because you are healthy

The speaker's position as the speaker (Pak Takeda) is a longtime customer of the restaurant. Compared to opposing interactions (Restaurant Owner). Socially speaking, it is higher, because the opponents of the interaction are people who work in the service sector.

Speakers toward their interaction partners use a variety of informal languages based on the choice of using an apology, that is 「ごめん、ごめん」

The choice of the phrase 「ご 無 沙汰」 states the speaker, keeps distance from the opponent, even though he used to meet frequently. Based on this, from the perspective of Japanese Social Interaction Patterns, the speaker puts himself as an outsider of the group ${ }^{\prime}(\ulcorner\vdash\lrcorner$ の

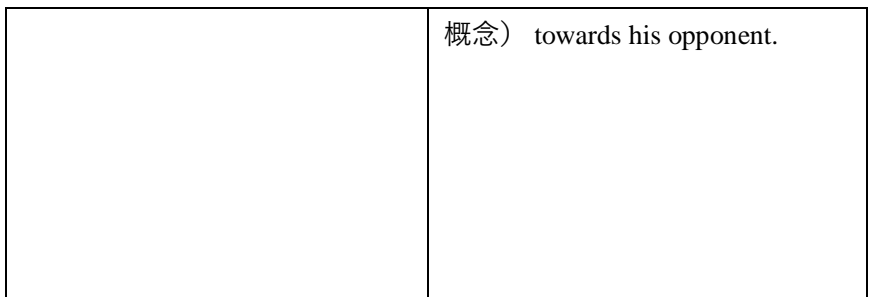

Story 2 店頭最大限の営業を(p.27-p.36)

\section{Maximizing Business At The Front Of The Restaurant}

In a restaurant at lunchtime, there is a conversation between visitors and visitors and between visitors and restaurant employees regarding the special room for smokers. Besides that, there was also a talk of payment between visitors and restaurant cashiers

A: Visitor 1 (non-smoker) B: Visitor 2 (smoker)

C: Visitor 3 (a group of office friends, a boss)

P1: Visitor 4, Yoshida (collection of office friends, subordinates)

P2: Visitor 5 (Smokers looking for ashtrays) W: Restaurant Cashier

Conversation situation:

Conversation between smokers and visitors who feel disturbed by the smoke, because the restaurant has no information about the separation of rooms for smokers
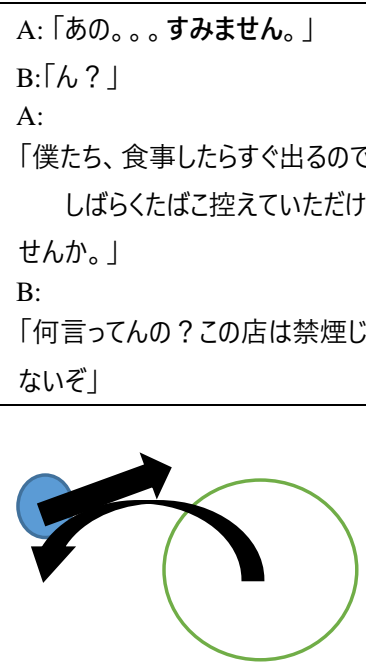

The speaker puts himself NOT the same area as the opponent's interactions

\section{A: "eerr... sorry"} B: "ng?"

A: "we will leave as soon as we finish eating, so can you please not smoke first?"

B: "What are you talking about? In this restaurant there is no smoking ban"
The speaker position as the speaker (non-smoker visitor), and the interaction partner is the same as his position, (visitors, but smokers)

Speakers of their interaction opponents use a variety of formal languages. Based on the choice of using an expression of apology, namely $「$ みませ $ん$ 」because, do not know each other

The function of 「すみません」is as a warning or also as an opening when you want to fight the interaction of doing what the speaker is talking about

The choice of command form 「--いただけ。せんか。」 states the speaker, keep distance from the opponent, based on that, from the point of view of Interaction Patterns in Japanese Social Society, the speaker puts himself as an 'outsider of the group' (「ソト」の 概念) against his opponent 
When a group of guests / visitors hold an office event will pay. Dialogue between fellow guests (P1 and P2) whose status is different from the restaurant cashier (W)

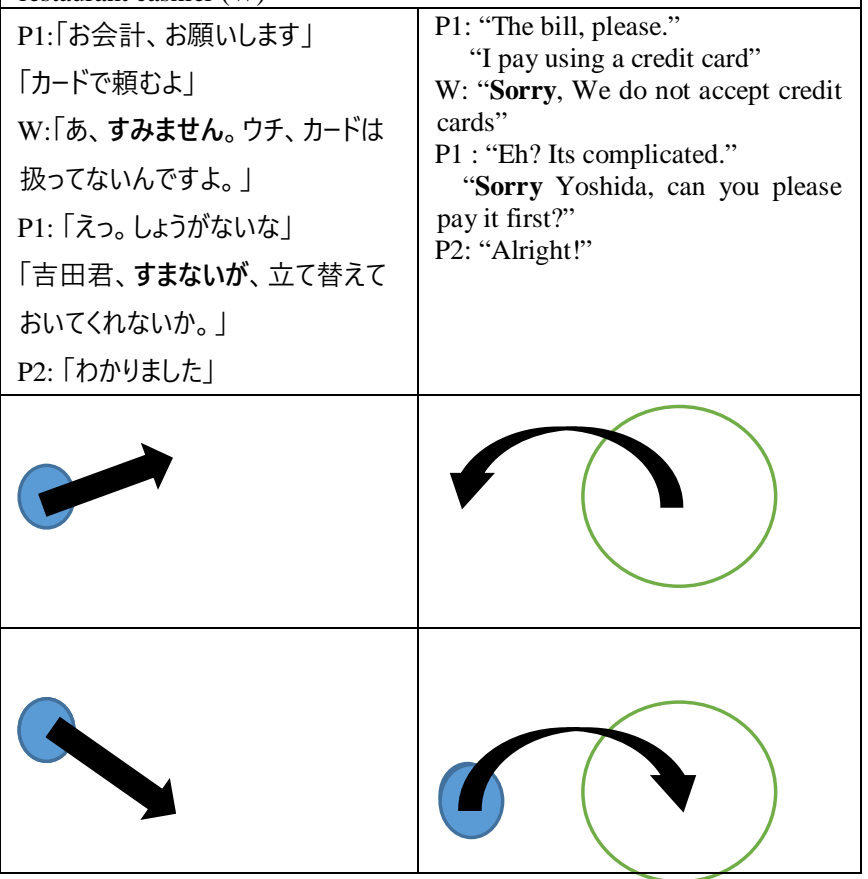

\section{CONCLUSION}

The choice of languages by the speaker, both as a speaker and as a respondent, is very dependent on the situation and condition of the speaker. There are interesting things, if viewed from the point of view of the Pattern of Interaction in Japanese Social Society. In general, if the speaker uses a variety of informal languages, it can be said that the speaker puts himself, becoming 'people in the group' towards his opponent. But some of the data of dialogue is precisely the opposite, that is the speaker puts himself TIDAK in the same area as the opponent's interaction, due to anger, or different social status.

\section{REFERENCES}

[1]山田泉1996『文化適応教育と日本語教育 2 社会派 日本語教育のすすめ』凡人社

[2]頼美麗『依頼場面における「謝罪」と「感謝」一「待遇コミュニケーション」 の観点から一』早稲田大学大学院日本語教育研究科博士論文2008 年 3 月

[3]＼cjkstart佐藤啓生『現代日本語の謝罪言葉に関する研究』岩[5] 手大学院人文社会学研究科紀要第20号2011年6月p.21-38

[4] 三宅和子2011「感謝と謝罪における「すみません」の選択メカニズム」『日 本語の対人関係把握と配慮言語行動』ひつじ書房 p. 25〜 51

[5] Chaer, Abdul kk, Sosiolinguistik Perkenalan Awal. Jakarta :Rineka Cipta, 2004.

[6] Doi, Takeo., Anatomi Dependensi: Telaah Psikologi Jepang. Jakarta: Gramedia, Penej: Arifin Bey, 1992.

[7] Doi, Takeo, Tsuzuki [Amae] no Kozo. Tokyo: Kobundo, 2001

[8] Benedict, Ruth, Kiku to Katana. Tokyo: Shisosha, Penj: Matsuji Tanikawa, 1972.

[9] Benedict, Ruth, The Chrisanthemum and the Sword. Tokyo: the Charles E. Tuttle Co, 1979.

[10] Benedict, Ruth, Pedang Samurai dan Bunga Seruni:Pola-pola Kebudayaan Jepang. Jakarta: Sinar Harapan, Penj Pamudji, 1982.

[11] Nakae, Chie, Masyarakat Jepang. Jakarta: Sinar Harapan, Penej: Bambang Kusriyanto, 1981.

[12] Reischauer, Edwind. O., Manusia Jepang:. Jakarta: Sinar Harapan., Penj Bakrie Siregar, 1982.

[13] Harada Akira, Ishikawa Morihiro. Tokyo: Nikkei Bussines Publications, Inc, 2011. 